\title{
ANGIOSTRONGYLUS CANTONESIS GÂY SỐT KHÔNG RÕ NGUYÊN NHÂN Ở TRÉ EM: BÁO CÁO CA BẸNH
}

\author{
Đỗ Thị Đài Trang1, $₫$, Nguyễn Sỹ Đức ${ }^{1}$, Nguyễn Văn Lâm² ${ }^{2}$ Phạm Gia Hân ${ }^{3}$ \\ ${ }^{1}$ Trường Đại học Y Hà Nội \\ ²Bệnh viện Nhi Trung ương
}

${ }^{3}$ Bệnh viện Đa khoa quốc tế Vinmec Times City

Sốt không rõ nguyên nhân (Fever of unknown orgin - FUO) ở trẻ em thường gây ra bởi các bệnh truyền nhiễm. Angiostrongylus cantonesis là căn nguyên chính gây viêm màng não tăng bạch cầu ái toan ở người, hiếm khi gây ra FUO. Chúng tôi báo cáo một trường hợp bệnh nhân 17 tháng tuổi với biểu hiện FUO, không có triệu chứng bất thường khác, bạch cầu ưa acid máu ngoại vi tăng cao (32\%). Chúng tôi chọc dịch não tủy để tìm nguyên nhân FUO, kết quả có > 2000 bạch cầu/ $\mu$ L (32\% bạch cầu ưa acid), phản ứng elisa huyết thanh và elisa dịch não tủy dương tính với Angiostrongylus cantonesis. Bệnh nhân được chẩn đoán viêm màng não tăng bạch cầu ái toan do Angiostrongylus cantonesis và đáp ứng tốt với điều trị. Kết luận: Ở trẻ nhỏ, triệu chứng nhiễm giun sán có thể không điển hình. Khi trẻ có biểu hiện FUO kèm bạch cầu ái toan trong máu ngoại vi tăng cao là dấu hiệu gợi ý nhiễm kí sinh trùng, đặc biệt chú ý nhiễm khuẩn thần kinh trung ương ngay cả khi không có triệu chứng lâm sàng.

Từ khóa: Sốt không rõ nguyên nhân (Fever of unknown orgin - FUO), viêm màng não tăng bạch cầu ái toan, Angiostrongylus cantonesis.

\section{I. ĐẠT VẤN ĐÈ}

Sốt không rõ nguyên nhân (FUO) được định nghĩa từ năm 1961 bởi Petersdorf và Beeson: Là tình trạng người bệnh có thời gian sốt kéo dài ít nhất 3 tuần với thân nhiệt $\geq 38,3^{\circ} \mathrm{C}$ trong hầu hết các ngày và vẫn chưa có chẩn đoán chắc chắn sau 1 tuần thăm khám và làm các xét nghiệm thăm dò tích cực. ${ }^{1}$ Hiện nay, FUO ở trẻ em được đề xuất là tình trạng sốt xảy ra trong hầu hết các ngày với thời gian sốt $\geq 14$ ngày mà quá trình hỏi bệnh sử, thăm khám lâm sàng và làm một số xét nghiệm cơ bản không tìm được nguyên nhân. ${ }^{2}$

Hơn $50 \%$ căn nguyên FUO ở trẻ em gây ra bởi các bệnh nhiễm trùng, chủ yếu là vi khuẩn, virus, nấm và một số loài kí sinh trùng. ${ }^{2}$ Angiostrongylus cantonesis (giun lươn não)

Tác giả liên hệ: Đỗ Thị Đài Trang,

Trường Đại học Y Hà Nội

Email: dothidaitrang@hmu.edu.vn

Ngày nhận: 12/07/2021

Ngày được chấp nhận: 30/08/2021 thuộc nhóm ký sinh trùng đường ruột và là căn nguyên chính gây viêm màng não tăng bạch cầu ái toan ở người, hiếm khi là nguyên nhân gây ra FUO. Catherine và cộng sự đã báo cáo hai ca bệnh FUO gây ra bởi Angiostrongylus cantonesis ở trẻ em. ${ }^{3}$

Bệnh ở người do ăn phải các vật chủ trung gian sống hoặc chưa chín kĩ hoặc thức ăn bị nhiễm ấu trùng giai đoạn ba. ${ }^{4}$, Âu trùng có ái lực với hệ thần kinh trung ương nên sau khi vào cơ thể người chúng di chuyển đến não và tủy sống. ${ }^{3}$ Vì vậy, bệnh nhân sẽ có biểu hiện buồn nôn, nôn vọt, đau đầu, gáy cứng, thóp phồng ở trẻ nhỏ và dị cảm, một số trường hợp nặng hơn sẽ biểu hiện viêm não (co giật, rối loạn tri giác, thậm chí hôn mê và tử vong). ., $6^{\circ}$

Các giai đoạn lâm sàng của viêm màng não tăng bạch cầu ái toan bao gồm: Giai đoạn ủ bệnh từ 3 đến 36 ngày (trung bình 15 ngày), bệnh nhân không có triệu chứng lâm sàng. Giai đoạn khởi phát có triệu chứng nhẹ như sốt, nhức đầu, 
chóng mặt, đau bụng, tiêu chảy. Tiếp theo là giai đoạn toàn phát với triệu chứng sốt cao, đau đầu dữ dội, buồn nôn, nôn vọt, sợ ánh sáng, nhìn đôi, dị cảm ngoài da. Giai đoạn này có thể kéo dài từ một đến hai tháng, thậm chí lâu hơn. Cuối cùng là giai đoạn hồi phục, các triệu chứng mất dần trong vài tuần tùy thuộc từng cá thể. ${ }^{6}$

Chẩn đoán viêm màng não tăng bạch cầu ái toan dựa vào biểu hiện lâm sàng, tiền sử dịch tễ học và số lượng bạch cầu ái toan (BCAT) tăng cao trong máu ngoại vi và dich não tủy. Việc chẩn đoán xác định nguyên nhân viêm màng não tăng bạch cầu ái toan do $A$. cantonesis dựa vào xét nghiệm elisa $A$. cantonesis trong huyết thanh hoặc PCR $A$. cantonesis trong dịch não tủy (DNT). ${ }^{7}$

Chúng tôi báo cáo một trường hợp bệnh nhi có biểu hiện FUO, không có bất kì triệu chứng nào của hội chứng não - màng não, BCAT trong máu ngoại vi và DNT tăng cao, tìm thấy kháng thể của $A$. cantonesis trong máu và dịch não tủy. Bệnh nhân được chẩn đoán viêm màng não tăng bạch cầu ái toan do $A$. cantonesis và đáp ứng điều trị tốt với thuốc tẩy giun và corticosteroid.

\section{BÁO CÁO CA BẸNH}

Bệnh nhân nam 17 tháng tuổi, được đưa đến khám tại Bệnh viện Nhi Trung ương với biểu hiện sốt 10 ngày, nhiệt độ dao động $38,5^{\circ} \mathrm{C}-39^{\circ} \mathrm{C}$ và không có biểu hiện bất thường nào khác. Trước đó, trẻ đã được điều trị nội trú tại bệnh viện tỉnh với chẩn đoán ban đầu là viêm họng cấp và dùng kháng sinh Ceftriaxone 5 ngày nhưng tình trạng sốt không cải thiện. Trẻ có tiền sử khỏe mạnh, đã được tiêm phòng đầy đủ, sống tại khu vực thành phố của một tỉnh miền núi phía Bắc, không tiếp xúc với chó mèo, trong nhà có một vườn rau rất nhiều ốc sên, trẻ hay chơi quanh khu vực vườn rau. Khi nhập viện, trẻ không ho, không nôn, không quấy khóc, ăn uống và đại tiểu tiện bình thường, khám các cơ quan thần kinh - hô hấp - tuần hoàn - tiêu hóa không ghi nhận triệu chứng bất thường.

Kết quả xét nghiệm ban đầu: Số lượng bạch cầu: $26 \mathrm{G} / \mathrm{l}$, bạch cầu trung tính: 9,1 G/l (35\%), bạch cầu ưa acid: $8,8 \mathrm{G} / \mathrm{l}(32 \%)$ và nồng độ CRP huyết thanh: $3 \mathrm{mg} / \mathrm{l}$. Xquang ngực thẳng bình thường. Cấy dịch tị hầu âm tính, PCR Mycoplasma pneumoniae dịch tị hầu âm tính, cấy máu âm tính và tổng phân tích nước tiểu bình thường. Nội soi tai mũi họng bình thường.

Trẻ được điều trị 8 ngày tại một khoa khác trước khi chuyển sang khoa của chúng tôi. Tại đây, qua thăm khám lâm sàng chúng tôi ghi nhận ngoài triệu chứng sốt kéo dài 18 ngày thì trẻ không có triệu chứng bất thường nào khác. Với tình trạng FUO và bạch cầu ái toan trong máu ngoại vi tăng cao, chúng tôi tập trung vào tìm các căn nguyên kí sinh trùng, đồng thời chọc dịch não tủy (DNT) tìm ổ nhiễm trùng tại thần kinh trung ương và tìm các căn nguyên FUO khác.

Kết quả xét nghiệm: DNT có > 2000 bạch cầu/ $/ \mathrm{L}$ (32\% bạch cầu ưa acid, 35\% bạch cầu lympho và $8 \%$ bạch cầu trung tính), glucose: 1,44 mg/dl, protein: 0,67 mg/dl, clo: $122 \mathrm{mmol} / \mathrm{l}$, phản ứng pandy dương tính. Chụp cộng hưởng từ sọ não (MRI) có hình ảnh giảm tỉ trọng dạng nang cạnh não thất bên bên trái và giãn nhẹ não thất (Hình 1). Cấy vi khuẩn DNT và $P C R$ lao trong DNT âm tính. Ngoài ra, PCR dịch não tủy với các tác nhân gây viêm màng não thường gặp như phế cầu, Haemophilus influenza type B, Escherichia coli, Herpes simplex virus (HSV), Enterorvirus (EV) âm tính. Một số xét nghiệm tìm nguyên nhân FUO: Các xét nghiệm loại trừ lao âm tính. PCR Epstein - Barr virus (EBV) âm tính, PCR Cytomegalovirus (CMV) âm tính, tủy đồ bình thường, kháng thể kháng chuỗi kép DNA âm tính, kháng thể kháng nhân âm tính, bổ thể bình thường. Xquang ngực thẳng chụp lần 2 : Dày thành phế quản, tù nhẹ góc sườn hoành phải. Cắt lớp vi tính lồng ngực: Đông đặc nhu mô thùy dưới phổi phải, không có dịch màng phổi. 
Các xét nghiệm tìm kí sinh trùng được thực hiện tại bệnh viện của chúng tôi, Viện Sốt rét - Kí sinh trùng - Côn trùng Trung ương và phòng khám của một bác sĩ đầu ngành chuyên ngành kí sinh trùng. Bệnh nhân được dùng Ceftriaxone 100 $\mathrm{mg} / \mathrm{kg} / \mathrm{ngày}$ trong thời gian chờ kết quả phân loại bạch cầu dịch não tủy và xét nghiệm khẳng định nhiễm kí sinh trùng.

\section{Bảng 1. Kết quả xét nghiệm kí sinh trùng}

\begin{tabular}{lcc}
\hline & Elisa dịch não tủy & Elisa huyết thanh \\
\hline Angiostrongylus cantonesis (Giun lươn não) & Dương tính & Dương tính \\
\hline Strongyloides stercoralis (Giun lươn) & Âm tính & Âm tính \\
\hline Toxocara canis (Giun đũa chó) & Âm tính & Âm tính \\
\hline Gnathostoma spinigerum (Giun đầu gai) & Âm tính & Âm tính \\
\hline Cysticerccus cellulosae (Ấu trùng sán lợn) & Âm tính & Âm tính \\
\hline Paragonimus spp (Sán lá phổi) & & Âm tính
\end{tabular}

Soi đáy mắt không thấy tổn thương của ấu trùng giun sán.

Bảng 2. Diễn biến kết quả xét nghiệm

\section{Máu ngoại vi}

Số lượng bạch cầu (G/l)

Số lượng bạch cầu trung tính - G/l (\%)

Số lượng bạch cầu ưa acid - G/l (\%)

Nồng độ CRP huyết thanh (mg/l)

\section{Dịch não tủy}

Số lượng bạch cầu (Tế bào/ $\mu \mathrm{l}$ )

Bạch cầu trung tính (\%)

Bạch cầu acid (\%)

Bạch cầu lympho (\%)

Bạch cầu mono (\%)

Protein (g/l)

Glucose ( $\mathrm{mmol} / \mathrm{l})$

Clo $(\mathrm{mmol} / \mathrm{l})$

Phản ứng Pandy
Trước điều trị

26

$9,1(35 \%)$

$8,8(32 \%)$

3,0

Trước điều trị

$>2000$

8

32

35

25

0,67

1,44

122

Dương tính

Dương tính

9,24

$2,67(28,9 \%)$

$1,55(16,8 \%)$

0,5

546

6

23

47

24

0,51

2,34

125

Sau điều trị 14 ngày

Sau điều trị 10 ngày

3




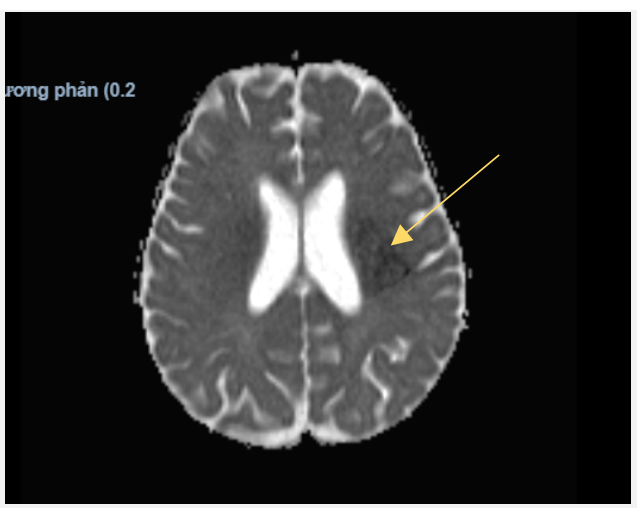

Trước điều trị

(Hình ảnh ổ giảm tỉ trọng dạng nang cạnh não thất bên bên trái và giãn nhẹ não thất 2 bên)

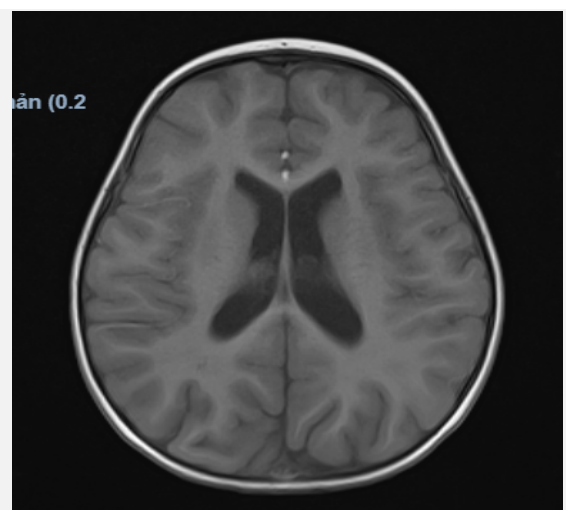

Sau điều trị

(Bình thường)

\section{Hình 1. Hình ảnh tổn thương não trên phim cộng hưởng từ}

Bệnh nhân được điều trị với liệu trình Albendazole (200 mg/ngày) uống trong 14 ngày và Dexamethasone tiêm tĩnh mạch $(0,6 \mathrm{mg} /$ kg/ngày chia 4 lần) trong 3 ngày đầu, sau đó chuyển sang Prednisolone uống $(1,5 \mathrm{mg} / \mathrm{kg} /$ ngày) và giảm liều dần. Sau 2 ngày điều trị, bệnh nhân hết sốt. Số lượng bạch cầu ái toan giảm và dịch não tủy cải thiện sau 10 ngày điều trị (Bảng 2), Bệnh nhân tái khám sau khi kết thúc điều trị, lâm sàng hoàn toàn ổn định, xquang ngực thẳng bình thường và cộng hưởng từ sọ não sau điều trị không còn thấy ổ tổn thương (Hình 1).

\section{BÀN LUẠN}

Angiostrongylosis là bệnh giun tròn do giống Angiostrongylus gây nên. Giống Angiostrongylus bao gồm trên 20 loài kí sinh chủ yếu ở chuột, trong đó có 2 loài gây bệnh ở người là Angiostrongylus cantonesis và Angiostrongylus costaricensis. Loài $A$. cantonesis được tìm ra năm 1935 trên chuột tại Trung Quốc, là kí sinh trùng phổ biến nhất gây viêm màng não tăng bạch cầu ái toan. Ca bệnh đầu tiên được báo cáo bởi Rosen và cộng sự năm 1962, được gọi là bệnh do "giun phổi chuột". 8
A. cantonesis chủ yếu gặp ở vùng Đông Nam Á, đặc biệt là Thái Lan, Malaysia và Việt Nam, cũng như rải rác khắp khu vực Thái Bình Dương bao gồm Đài Loan, Trung Quốc, Nhật Bản, Hawaii. Chuột là vật chủ chính của $A$. cantonesis. Sự thông thương kinh tế qua đường tàu biển giữa các quốc gia đã đưa những con chuột chứa A. cantonesis sang các khu vựa Châu Phi, Nam Mỹ, Úc, Cuba, Caribe... Vì vậy, một số ca bệnh nhiễm $A$. cantonesis đã được công bố ở các khu vựa này. ${ }^{5,9}$

Giun trưởng thành kí sinh trong phổi chuột, đẻ trứng và trứng nở thành ấu trùng theo phế quản và khí quản lên hầu rồi rơi xuống ruột và theo phân ra ngoài môi trường. Vật chủ trung gian là ốc ăn phải ấu trùng hoặc tự ấu trùng xâm nhập vào ốc để phát triển. Các yếu tố lây nhiễm $A$. cantonesis bao gồm: việc ăn ốc sên sống hoặc chưa nấu chín, các mảnh vỏ của ốc sên bám vào rau, nước ép rau, thực phẩm có chứa các chất nhờn của ốc sên và tay bị nhiễm bẩn trong quá trình chuẩn bị thức ăn. ${ }^{10,11}$

Ở người, ấu trùng $A$. cantonesis di chuyển vào mô thần kinh và mắt. Các triệu chứng thần kinh phát triển từ 3 đến 36 ngày sau khi nhiễm 
bệnh. Âu trùng vào não và gây viêm màng não tăng bạch cầu ái toan với các triệu chứng đau đầu dữ dội ( $90 \%$ trường hợp) thường đau vùng trán, thái dương hoặc chẩm, buồn nôn và nôn (67\%), sợ ánh sáng (92\%), tăng cảm giác đau (75\%), cứng gáy $(83 \%)$, co giật, liệt nhẹ, dị cảm $(50 \%){ }^{12}$ Một số trường hợp có biểu hiện viêm não và viêm tủy. Các triệu chứng thần kinh sẽ cải thiện tốt sau khi được điều trị. Theo Wang QP và cộng sự nghiên cứu trên 114 trẻ bị viêm màng não tăng bạch cầu ái toan do $A$. cantonesis cho thấy triệu chứng sốt ở trẻ em xảy ra ở $80 \%$ trường hợp, tỉ lệ này cao hơn ở người lớn (32\%), trẻ thường sốt nhẹ hoặc sốt thoáng qua, sốt xuất hiện cùng các triệu chứng thần kinh khác, rất hiếm khi gặp FUO. ${ }^{3,10}$ Báo cáo của Catherine và cộng sự cho thấy $A$. cantonesis gây FUO ở hai trẻ 13 tháng tuổi và 19 tháng tuổi, tuy nhiên sau đó cả 2 trẻ này đều xuất hiện các triệu chứng thần kinh. ${ }^{3}$ Bệnh nhân của chúng tôi chỉ có biểu hiện sốt trong suốt quá trình bệnh mà không có bất kì triệu chứng thần kinh nào khác. Âu trùng $A$. cantonesis không chỉ xuất hiện trong dịch não tủy mà có thể có trong tiền phòng hay thủy tinh thể của mắt và thậm chí trong động mạch phổi. Tại mắt, bệnh nhân có thể biểu hiện nhìn mờ một bên, song thị hoặc lác mắt mà không có dấu hiệu của viêm màng não. ${ }^{7,12}$ Trường hợp ấu trùng xâm nhập qua đường tiêu hóa có thể gây triệu chứng đau bụng, tiêu chảy hoặc qua phổi và khí quản gây ho, đau họng. ${ }^{13}$ Tổn thương phổi ở bệnh nhân của chúng tôi có thể là do $A$. cantonesis di cư qua phổi gây ra vì không tìm được căn nguyên vi sinh khác và bệnh nhân đáp ứng với điều trị.

Ngoài các biểu hiện lâm sàng, tiền sử dịch tễ học và số lượng BCAT trong máu ngoại vi tăng (73\% trường hợp) và BCAT trong DNT tăng (79\% trường hợp), việc chẩn đoán xác định căn nguyên dựa vào xét nghiệm elisa $A$. cantonesis trong huyết thanh hoặc PCR $A$. cantonesis trong
DNT. Tuy nhiên, xét nghiệm PCR A. cantonesis trong DNT chưa sẵ có tại Việt Nam, chúng tôi gửi bệnh phẩm sang các cơ sở y tế chuyên khoa để xét nghiệm elisa $A$. cantonesis trong huyết thanh và gián tiếp sử dụng xét nghiệm elisa $A$. cantonesis trong DNT để chẩn đoán. Số lượng bạch cầu trong DNT có thể dao động từ 20 đến 5000 tế bào/mm $/ \mathrm{mm}^{3}$ (thường từ 150 - 2000 tế bào/ $\mathrm{mm}^{3}$ ), trong đó > 10\% BCAT (bạch cầu ái toan DNT dao động 20 - 70\%), glucose bình thường hoặc giảm nhẹ, protein tăng cao. Tăng BCAT máu ngoại vi thường song song với tăng BCAT trong DNT ở phần lớn các trường hợp, tuy nhiên mức độ tăng BCAT trong máu và DNT không tương quan với mức độ nặng của bệnh. Bạch cầu ái toan máu ngoại vi trở về bình thường sau điều trị nhiều tuần đến nhiều tháng. ${ }^{7}$

Hiện nay, khuyến cáo điều trị $A$. cantonesis nên dùng đồng thời thuốc tẩy giun và corticosteroid. Thuốc diệt $A$. cantonesis bao gồm nhóm benzimidazole (Albendazole, mebendazole, thiabendazole và fenbendazole), ivermectin và levamisole. Trong đó albendazole là chựa chọn tốt nhất để điều trị $A$. cantonesis vì thuốc ngấm tốt qua hàng rào máu não, đạt nồng độ cao trong DNT so với các benzimidazole khác. Khả năng hấp thu của thuốc tăng lên gấp 5 lần nếu được uống sau bữa ăn với đồ ăn chứa nhiều chất béo. Liều albendazole là $15 \mathrm{mg} / \mathrm{kg} /$ ngày chia 2 lần, dùng trong 14 ngày. Thuốc có hiệu quả nhất sau 5 - 14 ngày và có tác dụng tiêu diệt nhanh ấu trùng. ${ }^{7}$ Việc sử dụng thuốc tẩy giun đã gây tranh cãi trong nhiều thập kỉ qua với lo ngại ấu trùng chết nhanh sẽ giải phóng các chất trung gian viêm làm nặng lên các triệu chứng thần kinh. Tuy nhiên các nghiên cứu trên thực nghiệm và lâm sàng cho thấy việc dùng albendazole vẫn mang lại nhiều lợi ích. Ở trẻ em, corticosteroid nên sử dụng sớm, liều cao với prednisolone 1 - 1,5 mg/kg/ngày (không quá 80 mg/ngày) hoặc dexamethasone 0,6 - 1mg/ 
kg/ngày chia nhiều lần trong ngày. Thời gian dùng corticosteroid trung bình 14 ngày và giảm liều từ từ. Trường hợp bệnh nhân xuất hiện các triệu chứng nặng hơn hoặc tái phát cần duy trì corticosteroid kéo dài hơn. Một số trường hợp nhẹ không cần dùng corticosteroid. Viêm màng não do $A$. cantonesis có tiên lượng tốt nếu được điều trị đúng và ít để lại di chứng nặng nề. ${ }^{7,14}$

Nhiễm $A$. cantonesis ở trẻ nhỏ khác so với trẻ lớn và người lớn vì các triệu chứng thường không đặc hiệu và biểu hiện lâm sàng không đầy đủ. Hầu hết các trường hợp nhiễm kí sinh trùng ở trẻ em, toàn trạng chung có thể hoàn toàn ổn định, các triệu chứng âm ỉ và diễn biến không rầm rộ như nhiễm virus, vi khuẩn. Bệnh nhân của chúng tôi là một trường hợp đặc biệt vì tuổi còn khá nhỏ và chỉ có biểu hiện sốt kéo dài mà không có bất kì triệu chứng thần kinh nào. Tổng thời gian sốt tới thời điểm chọc DNT và tìm được nguyên nhân là 20 ngày. Với chẩn đoán viêm màng não tăng bạch cầu ái toan do $A$. cantonesis, bệnh nhân được điều trị corticosteroid và thuốc tẩy giun Albendazole, đây là thuốc an toàn và hiệu quả để diệt ấu trùng A. cantonesis ở trẻ nhỏ. Với liệu trình điều trị đủ ngày theo đúng phác đồ, bệnh nhân đáp ứng hoàn toàn và không có biến chứng, di chứng.

\section{KÉT LUẬN}

Ở trẻ nhỏ, triệu chứng nhiễm giun sán có thể không điển hình. Khi trẻ sốt không rõ nguyên nhân (FUO) kèm bạch cầu ái toan trong máu ngoại vi tăng cao là dấu hiệu gợi ý cần loại trừ nhiễm kí sinh trùng, đặc biệt chú ý tới nhiễm khuẩn thần kinh trung ương ngay cả khi bệnh nhân không có triệu chứng lâm sàng.

\section{TÀI LIỆU THAM KHẢO}

1. Petersdorf RG, Beeson PB. Fever of unknown origin: report on 100 cases. Medicine (Baltimore) 1961;40(1):1-30. doi: 10.1097/00005792 - 196102000 - 00001.
2. Marshall GS. Prolonged and recurrent fevers in children. Journal of Infection 2014; 68(Suppl 1): S83-93. doi: 10.1016/j. jinf.2013.09.017.

3. Catherine E.F, Erin G.N, Angela C.C, et al. Angiostrongylus cantonensis Infection: A Cause of Fever of Unknown Origin in Pediatric Patients. Infectious Diseases Society of America 2016;63(11): 1475 - 1478. doi:10.1093/cid/ ciw606.

4. Monteiro MD, de Carvalho Neto EG, Dos Santos IP, et al. Eosinophilic meningitis outbreak related to religious practice. Parasitol Int 2020;78:102158. doi: 10.1016/j. parint.2020.102158.

5. Barratt J, Chan D, Sandaradura I, et al. Angiostrongylus cantonensis: a review of its distribution, molecular biology and clinical significance as a human pathogen. Parasitology 2016;143:1087. doi: 10.1017/ S0031182016000652.

6. Tsai HC, Lee SS, Huang CK, et al. Outbreak of eosinophilic meningitis associated with drinking raw vegetable juice in southern Taiwan. Am J Trop Med Hyg 2004;71:222. DOI:10.4269/ ajtmh.2004.71.222

7. Ansdell V, Kenton J, Jourdan K, et al. Guidelines for the diagnosis and treatment of neuroangiostrongyliasis: updated recommendations: updated recommendations. Parasitology 2021;148, 227-233. doi: 10.1017/ S0031182020001262.

8. Joseph E. Angiostrongyliasis Cantonensis (Eosinophilic Meningitis): Historical Events in its Recognition as a New Parasitic Disease of Man. Journal of the Washington Academy of Sciences 1988;78(1): 38 - 46.

9. Waugh CA, Lindo JF, Lorenzo - Morales J, et al. An epidemiological study of $A$. cantonensis in Jamaica subsequent to an outbreak of human cases of eosinophilic meningitis in 2000. Parasitology 2016;143:1211. doi: 10.1017/ 
S0031182016000640.

10. Wang QP, Lai DH, Zhu XQ, et al. Human angiostrongyliasis. The Lancet infectious diseases 2008;8(10): 621 - 630. doi: 10.1016/ S1473 - 3099(08)70229 - 9.

11. Centers for Disease Control and Prevention. Parasites - Angiostrongyliasis (also known as Angiostrongylus Infection): Disease. https://www.cdc.gov/parasites/angiostrongylus/ disease.html (Accessed on September 29, 2017).

12. Murphy GS and Johnson S. Clinical aspects of eosinophilic meningitis and meningoencephalitis caused by Angiostrongylus cantonensis, the rat lungworm. Hawaii $\mathrm{J}$ Med Public Health 2013,72: 35-4

13. Martinsa YC, Tanowitza HB, Kazacosb KR. Central nervous system manifestations of Angiostrongylus cantonensis infection. Acta Trop 2015;141PA: 46-53. doi: 10.1016/j. actatropica.2014.10.002

14. Chotmongkol V, Kittimongkolma S, Niwattayakul K, et al. Comparison of prednisolone plus albendazole with prednisolone alone for treatment of patients with eosinophilic meningitis. Am J Trop Med Hyg 2009;81:443.

\section{Summary}

\section{ANGIOSTRONGYLUS CANTONESIS CAUSES FEVER OF UNKNOWN ORIGIN IN CHILDREN: A CASE REPORT}

Fever of unknown origin (FUO) in children is frequently caused by infectious diseases. Angiostrongylus cantonesis, while a primary cause of eosinophilic meningitis, is a rare cause of FUO. We report a 17-month-old patient admitted with FUO, no sign and symptom of meningococcal disease, but had elevated peripheral eosinophils count (32\%). We performed lumbar puncture to find the cause of FUO. The results was greater than 2000 leukocytes/ $\mu \mathrm{l}$ (32\% eosinophils), Elisa serum and CSF was positive with Angiostrongylus cantonesis. The patient was diagnosed with eosinophilic meningitis caused by Angiostrongylus cantonesis and responded well with treatment. Conclusion: In young children, symptoms of parasites infections may be atypical. In children with FUO and elevated peripheral blood eosinophils, the physicians need to carefully review the medical history and examine patients to identify parasites infection, with special focus on central nervous system infection.

Keywords: Fever of unknown origin (FUO), eosinophilic meningitis, Angiostrongylus cantonesis. 